\title{
Molecular identification and virulence factors of pseudomonas aeruginosa strains isolated from animal products
}

\begin{abstract}
Pseudomonas aeruginosa is an opportunistic pathogen which is characterized by its capacity to develop resistance and virulence factors. Despite their knowledge, these resistance and virulence factors are not more characterized at level of strains from local food. This study aimed to detect the presence of various virulence factors and metallo$\beta$-lactamase-producing P. aeruginosa from animal products. One hundred (100) strains of Pseudomonas aeruginosa were isolated from bovine meat (60), fresh fish (24) and smoked fish (16). API20NE methods, IPM-EDTA disk method and polymerase chain reaction (PCR) using the $\mathrm{rpoB}$, lasB, exoS, algD, and $\mathrm{plcH}$ gene were performed. The rpoB gene confirmed $99.0 \%$ of presumptive strains as Pseudomonas aeruginosa. All of virulence genes studied were detected in decreasing importance order, lasB $(89.0 \%)$, exoS $(84.0 \%)$, algD $(73.0 \%)$ and $\mathrm{plcH}(71.0 \%)(\mathrm{p}<0.05)$. A percentage of $22.0 \%$ of animal strains were P. aeruginosa producing MBLs. The simultaneous determination of virulence factors and metallo- $\beta$-lactamase is of interest for the efficacy of surveillance of infections associated with P. aeruginosa.
\end{abstract}

Keywords: pseudomonas aeruginosa, mbls, bovine meat, fresh fish, smoked fish, PCR
Volume 4 Issue 3 - 2017

\author{
Comoé Koffi Donatien Benie, $1^{2}$ Adjéhi \\ Dadie, 1,2 Nathalie Guessennd, 2,3 N'zebo \\ Désiré Kouame,' Nadège Ahou N'gbesso- \\ Kouadio,' Solange Aka, ' Koffi Marcellin DJE,' \\ Mireille Dosso ${ }^{2,3}$ \\ 'University of Nangui-Abrogoua, Côte d'Ivoire \\ ${ }^{2}$ Department of Bacteriology and Virology, Institut Pasteur of \\ Côte d'Ivoire (IPCl), Côte d'lvoire \\ ${ }^{3}$ University of Félix Houphouët Boigny, Côte d'Ivoire
}

Correspondence: Comoé Koffi Donatien Benie, Department of Bacteriology and Virology, Institut Pasteur of Côte d'Ivoire (IPCI), 0I BP 490 Abidjan 01, Côte d'Ivoire, Tel +2250755 58 44/+22505 2064 44, Email dona.comoer@yahoo.f

Received: January 31, 2017 | Published: April 06, 2017

\section{Introduction}

Microorganisms are the primary cause of food spoilage and food borne illness. ${ }^{1,2}$ Among these germs, Pseudomonas aeruginosa occupies a large place in food contamination. It contaminates domestic and wild animals, human beings, plants, drinking water, and is also isolated from variety foods. ${ }^{3,4}$ This psychrotrophic germ is specific spoilage organisms (SSO) of meat, poultry and fish. ${ }^{4}$

Pseudomonas aeruginosa is an opportunistic pathogen capable of infecting virtually all tissues. ${ }^{5}$ It possesses a variety of virulence factors that may contribute to its pathogenicity. ${ }^{5,6}$ It has also a large number of virulence factors such as, Exo enzyme $\mathrm{S}$, encoded by the exoS gene that is secreted by a type-III secretion system. ${ }^{5,6}$ Phospholipases C (PLCs) are also implicated in virulence. Pseudomonas aeruginosa produces three PLCs: one with hemolytic activity $(\mathrm{PlcH})$, one other non-hemolytic $(\mathrm{PlcN})$ and the last, a PLcB which is important for chemotaxis and plays an important role in "twiching" mobility. ${ }^{5-7}$

A phosphate deficiency induces the production of $\mathrm{PlcH}$. These PLCs are secreted via the type-II secretion system. ${ }^{5,6}$ Others genes are implicated in Pseudomonas aeruginosa virulence: LasB elastase, a zinc metalloprotease encoded by the LasB gene, has an elastolytic activity on lung tissue. ${ }^{5,7}$ Mucoid colonies composed of alginates produced by Pseudomonas aeruginosa, involving algD genes protect the bacteria from the host immune responses and biocides (antiseptic, disinfectant and antibiotic). ${ }^{6,8}$

This production of alginates therefore makes the strains of $P$. aeruginosa multi-resistant. These multi-resistant strains can harbor and produce certain resistance genes such as metallo- $\beta$-lactamase
(MBL). ${ }^{9} 10$ Those metallo-enzymes are capable to inactivate $\beta$-lactam antibiotics such as carbapenems, penicillins and cephalosporins. ${ }^{10-12}$ These enzymes promote the involvement of $P$. aeruginosa in foodborne diseases and nosocomial infections in various regions of the world. ${ }^{2,10,13}$ The strains of $P$. aeruginosa metallo- $\beta$-lactamaseproducing $(\mathrm{M} \beta \mathrm{L})$ are also responsible for serious infections such as septicemia and pneumonia. ${ }^{14}$ Thus, several phenotypic methods can be used to determine strains of Pseudomonas aeruginosa producing metallo- $\beta$-lactamase of various origins. ${ }^{9,15}$

In addition, PCR allows rapid and complete identification of Pseudomonas aeruginosa. ${ }^{5,16}$ This method also allows the determination of resistance and virulence genes associated with this bacterium. The relationship between animal products, resistance to antimicrobials and virulence factors of Pseudomonas aeruginosa are not widely studied. This study aimed to detect the presence of various virulence factors and metallo- $\beta$ lactamase-producing $P$. aeruginosa.

\section{Materials and methods}

\section{Isolation of P. aeruginosa from animal products}

The studies were carried out in and around market of Abidjan district (Côte d'Ivoire). A total of one hundred (100) isolates of $P$. aeruginosa were used in the present study. The isolates were obtained from different samples of animal products, including beef (57), fresh fish (23) and smoked fish (18). The samples were collected from local market and put in sterile Stomacher bags, stored at $4{ }^{\circ} \mathrm{C}$, and analyzed within 30minutes of collection. Ten (10) g of the flesh of each bovine meat, fresh fish and smoked fish sample were homogenized in $90 \mathrm{ml}$ peptone water, and then, serial decimal dilutions were prepared. 
Amount of $0.1 \mathrm{ml}$ of each dilution was spread on the selective medium Pseudomonas cetrimide agar (PCA) using a spreading technique. Plates were incubated at $44^{\circ} \mathrm{C}$ for 18 -24hours and observed for suspected colonies of $P$. aeruginosa.

\section{Morphological and biochemical characterization}

Gram's reaction- Gram's staining, Motility determination-Hanging drop method and Motility test were carried out for the morphology of cell. Biochemical identification of the isolates was carried out using API 20NE (bioMérieux, Marcy l'Etoile, France) and the API database.

\section{Phenotypic detection of MBL activity}

All strains that showed reduced susceptibility to imipenem $\geq 8 \mathrm{~g}$ / $\mathrm{ml}$ were screened for MBL production. These strains were subjected to a phenotypic analysis by EDTA (Sigma Chemicals, St. Louis, MO) combination disk test. ${ }^{17}$ Briefly, a 18 hours culture of animal isolate was diluted with peptone water (Oxoid, USA) corresponded to the $0.5 \mathrm{McF}$ arland standard, which is approximately $108 \mathrm{CFU} / \mathrm{ml}$ and spread on Mueller-Hinton agar (Oxoid Ltd., Basingstoke, Hampshire, England) plate using cotton swab. Two IPM $(10 \mu \mathrm{g})$ disks were placed on the surface of the agar at distances of $20 \mathrm{~mm}$ away from each other. Then, $4 \mu \mathrm{L}$ of EDTA ( $0.5 \mathrm{M}, \mathrm{pH}$ 8) solution was added to one of the IPM $(10 \mu \mathrm{g})$ disks. Another IPM disk $(10 \mu \mathrm{g})$ was placed at $20 \mathrm{~mm}$ center to center of a sterile non-impregnated disk on which $10 \mu \mathrm{l}$ of EDTA (0.5 M, pH 8) has been added.

The inhibition zones displayed around the IPM and the IPMEDTA disks were compared after 18 to $24 \mathrm{hrs}$ incubation at $37^{\circ} \mathrm{C}$. The difference of $\geq 7 \mathrm{~mm}$ between the inhibition zone diameter of the IPMEDTA disk and that of the IPM $(10 \mu \mathrm{g})$ alone disk was considered to be a positive test for the presence of MBLs. ${ }^{14}$ P. aeruginosa PA105663 producing IMP-7; $P$. aeruginosa $\mathrm{PS} 679 / 00$ producing VIM-2; and $P$. aeruginosa ATCC 27853 were used as positive and negative controls.

\section{Molecular Identification of Pseudomonas aeruginosa}

Extraction and purification of DNA: Template DNA was extracted from whole organisms by boiling [18]. Bacteria were harvested from an overnight broth culture (Biokar Diagnostics, BK015HA, France), suspended in $1 \mathrm{ml}$ sterile Milli-Q water (milli-Q ${ }^{\mathrm{TM}}$, Millipore Corporation, USA). A suspension of $200 \mu 1$ was incubated at $-20^{\circ} \mathrm{C}$ for 15 minutes and boiled at $95^{\circ} \mathrm{C}$ for 15 minutes.

The suspension was immediately cooled at $4^{\circ} \mathrm{C}$ for 10 minutes and then centrifuged at $14000 \mathrm{rpm}$ for 10 minutes to pellet the cell debris. The DNA template was purified according to the method described by Zimmermann et al. ${ }^{19}$ The purity and DNA concentration of the extract Table 1 Primers used for amplification of virulence genes in multiplex PCR were determined by spectrophotometer (Eppendorf BioPhotometer plus, USA).

\section{PCR amplification}

Single PCR for characterization of rpoB gene was carried out with a total volume of $25 \mu \mathrm{l}$ consisted of $16 \mu \mathrm{l}$ of sterile Milli-Q water (milli- $\mathrm{Q}^{\mathrm{TM}}$, Millipore Corporation, USA), $5 \mu \mathrm{l}$ of $5 \mathrm{XTP}, 1.5 \mu \mathrm{l}$ of $\mathrm{MgCl} 2(2 \mathrm{mM}), 0.2 \mu \mathrm{l}$ of dNTPs $(10 \mathrm{~mm}), 0.1 \mu \mathrm{l}$ of each primer (20mM) (Integral DNA Technology, California, U. S. A) (rpoB F: Order No. 2512433, Ref. No. 70393602; rpoB R: Order No. 2512433, Ref. No. 70393603), $0.1 \mu \mathrm{l}$ of Go tag polymerase (Promega Corporation, Madison, WI 53711-5399, USA) and $2 \mu \mathrm{l}$ of DNA matrix. DNA rpoB region amplification was performed using the primer set rpoB F (5'-CAGTTCATGGACCAGAACAACCCG-3') and rpoB R (5'ACGCTGGTTGATGCAGGTGTTC-3'), aligning on positions 1552 and 2298 of the rpoB gene sequence of Pseudomonas aeruginosa UCBPP-PA14 (CP000438). ${ }^{20-22}$

The rpoB DNA was amplified using the following protocol: initial denaturation at $94^{\circ} \mathrm{C}$ for $3 \mathrm{~min}$, followed by 35 cycles of denaturation at $94^{\circ} \mathrm{C}$ for $1 \mathrm{~min}$, annealing at $58^{\circ} \mathrm{C}$ for $1 \mathrm{~min}$ and extension at $72^{\circ} \mathrm{C}$ for $2 \mathrm{~min}$, with a single final extension of $7 \mathrm{~min}$ at $72^{\circ} \mathrm{C}$. Amplification was performed with $10 \mu 1$ of PCR products which were separated in $1.5 \%$ agarose gel for $30 \mathrm{~min}$ at $120 \mathrm{~V}$. After amplification, the agarose gel was put in ethidium bromide $(0.5 \mu \mathrm{g} / \mathrm{ml})$ and detected by Molecular Imager Gel DocTM EZ (Bio-Rad, USA).

Multiplex PCRs were used to detect lasB, exoS, algD and plcH. PCR mixtures with a final volume of $25 \mu$ l consisted of $15.8 \mu l$ sterile Milli-Q water (milli-Q ${ }^{\mathrm{TM}}$, Millipore Corporation, USA), $5 \mu 1$ XXT, $1.5 \mu \mathrm{l} \mathrm{MgCl} 2(2 \mathrm{mM}), 0.2 \mu \mathrm{l}$ dNTPs $(10 \mathrm{mM}), 0.1 \mu \mathrm{l}$ each primer $(20 \mathrm{mM})$ (Integral DNA Technology, France), $0.1 \mu \mathrm{l}$ Go tag polymerase (Promega Corporation, Madison, WI 53711-5399, USA) and $2 \mu \mathrm{l}$ DNA template. A quantity of $2 \mu \mathrm{l}$ of sterile Milli-Q water was used for negative control and DNA of ATCC reference strain 27853 used for positive control.

The oligonucleotide primers used in this study and the amplification program are listed in Table 1. Each PCR was performed using thermocycler type T3000 thermocycler, Block type standard 3a, (Biometra, Germany). The amplified DNA was separated by gel electrophoresis with $2 \%$ agarose containing $0.5 \mu \mathrm{g} / \mathrm{ml}$ with ethidium bromide for $30 \mathrm{~min}$ at $130 \mathrm{~V}$, visualized under UV transillumination and photographed (Molecular Imager Gel DocTM XR+, Bio-Rad). Amplified genes were identified on the basis of fragment size shown in Table 1.

\begin{tabular}{|c|c|c|c|c|c|c|}
\hline Primers & $\begin{array}{l}\text { Target } \\
\text { gene }\end{array}$ & Sequence (5'-3') & $\begin{array}{l}\text { Product size } \\
\text { (bp) }\end{array}$ & Amplification program & $\begin{array}{l}\text { Annealing } \\
\text { temperature }\left({ }^{\circ} \mathrm{C}\right)\end{array}$ & Source \\
\hline $\begin{array}{l}\text { LasB-F } \\
\text { LasB-R }\end{array}$ & LasB & $\begin{array}{l}\text { GGA ATG AAC GAG GCG } \\
\text { TTC TC } \\
\text { GGT CCA GTA GTA GCG } \\
\text { GTT GG }\end{array}$ & 300 & $\begin{array}{l}94^{\circ} \mathrm{C}, 5 \min \\
35 \times\left[94^{\circ} \mathrm{C}, 35 \mathrm{~s} ; 60^{\circ} \mathrm{C}, 1 \mathrm{~min} ; 72^{\circ} \mathrm{C}, 1 \mathrm{~min}\right] \\
72^{\circ} \mathrm{C}, 7 \mathrm{~min} ; 4^{\circ} \mathrm{C} \ldots\end{array}$ & 60 & 23 \\
\hline $\begin{array}{l}\text { ExoS-F } \\
\text { ExoS-R }\end{array}$ & exoS & $\begin{array}{l}\text { CTT GAA GGG ACT CGA } \\
\text { CAA GG } \\
\text { TTC AGG TCC GCG TAG } \\
\text { TGA AT }\end{array}$ & 504 & & & 23 \\
\hline
\end{tabular}


Table Continued

\begin{tabular}{|c|c|c|c|c|c|c|}
\hline $\begin{array}{l}\text { algD-F } \\
\text { algD-R }\end{array}$ & $\operatorname{algD}$ & $\begin{array}{l}\text { ATG CGA ATC AGC ATC } \\
\text { TTT GGT } \\
\text { CTA CCA GCA GAT GCC } \\
\text { CTC GGC }\end{array}$ & 1310 & $\begin{array}{l}94^{\circ} \mathrm{C}, 5 \mathrm{~min} \\
35 \mathrm{x}\left[94^{\circ} \mathrm{C}, 35 \mathrm{~s} ; 61^{\circ} \mathrm{C}, 1 \mathrm{~min} ; 72^{\circ} \mathrm{C}, 1 \mathrm{~min}\right]\end{array}$ & 62 & 23 \\
\hline $\begin{array}{l}\text { plcH-F } \\
\text { plcH-R }\end{array}$ & $\mathrm{plcH}$ & $\begin{array}{l}\text { GAA GCC ATG GGC TAC } \\
\text { TTC AA } \\
\text { AGA GTG ACG AGG } \\
\text { AGC GGTAG }\end{array}$ & 307 & $72^{\circ} \mathrm{C}, 7 \mathrm{~min} ; 4^{\circ} \mathrm{C} \ldots$ & 60 & 23 \\
\hline
\end{tabular}

\section{Statistical analysis}

The statistical analysis was carried out on the software Statistical Package for the Social Sciences (SPSS) 20.0 (IBM SPSS, Chicago, IL, United States of America) using the Student's t test, Mann-Whitney U test, Spearman's correlation analysis and multiple regression analysis. Statistical significance was set at $\mathrm{p}<0.05$.

\section{Results}

\section{Morphological and biochemical characterization}

Pseudomonas aeruginosa is a motile, Gram negative, facultative, rod-shaped bacterium measuring 0.5 to $0.8 \mu \mathrm{m}$ by 1.5 to $3.0 \mu \mathrm{m}$ in size. It is resistant to high concentrations of salts and dyes, weak antiseptics, and many commonly used antibiotics. Its optimum temperature for growth is $37^{\circ} \mathrm{C}$, but retains a growth potential at temperatures as high as $42^{\circ} \mathrm{C}$. P. aeruginosa strains produce two types of soluble pigments, a fluorescent pigment pyoverdin, and a blue pigment, pyocyanin.

\section{Pseudomonas aeruginosa strains isolated}

Out of 112 presumptive isolates of Pseudomonas aeruginosa, $101(90.1 \%)$ were identified by API 20NE (Table 2). The rpoB gene confirmed $100(99.0 \%)$ of these strains as Pseudomonas aeruginosa out of $101(90.1 \%)$ (Figure 1).

\section{Prevalence of virulence genes among all studied P. aeruginosa isolates}

Figure 2 to Figure 4 showed that all the virulence genes studied in this study were detected in the 100 strains of Pseudomonas aeruginosa. According to the Figure 2 and Figure 3 lasB gene with $89.0 \%$ has been most detected following by exoS $(84.0 \%)$. The prevalence of algD and plcH gene was respectively $73.0 \%$ and $71.0 \%$ (Figure 2) (Figure 4).

\section{Prevalence of Pseudomonas aeruginosa virulence genes in animal products}

The prevalence of virulence genes studied was higher than 50\% in all animal products analyzed. The prevalence of lasB and exoS genes was respectively higher in bovine meat $(96.7 \%, 93.3 \%)$, followed by smoked fish $(87.5 \%, 75.0 \%)$ and fresh fish $(70.8 \%, 66.7 \%)$ (Figure 5). That of algD and plcH gene was respectively higher in fresh fish $(79.2 \%, 75.0 \%)$ followed by bovine meat $(75.0 \%, 71.1 \%)$ and smoked fish $(56.3 \%, 62.5 \%)$ (Figure 5$)$.

\section{Metallo- $\beta$ actamase and virulence patterns}

The strains of Pseudomonas aeruginosa producing elastase (lasB) and harboring the alginate (algD) showed the same percentage of blaIMP genes $73.3 \%$ (Figure 6). Those strains whish secreted exoenzyme (exoS) and harboring the alginate (algD) showed the same percentage of blaVIM genes $66.7 \%$ (Figure 7). The strains of Pseudomonas aeruginosa harboring the $\mathrm{PlcH}$ gene indicated a production of metallo- $\beta$ lactamase (VIM and IMP) of less than $50 \%$ (Figure 6).

\section{Screening for and confirmation of MBLs}

Phenotypic methods indicated that $22(22.0 \%)$ of the 100 strains studied were $P$. aeruginosa producing MBLs using (Figure 7).

Table 2 Frequency of strains confirmed by the API $20 \mathrm{NE}$ and rpoB genes

\begin{tabular}{lll}
\multicolumn{3}{l}{ Number of isolates presumptive $\boldsymbol{p}$. a a ruginosa $\mathbf{N}=112$} \\
\hline $\begin{array}{l}\text { Identification of } \\
\text { P. aeruginosa }\end{array}$ & $\begin{array}{l}\text { Phenotypic and } \\
\text { biochemical }\end{array}$ & $\begin{array}{l}\text { Molecular } \\
\text { (rpoB gene) }\end{array}$
\end{tabular}

(API 20NE)

Effective (N) $\quad 101 \quad 100$

Percentage $(\%) \quad 90.1 \quad 99$




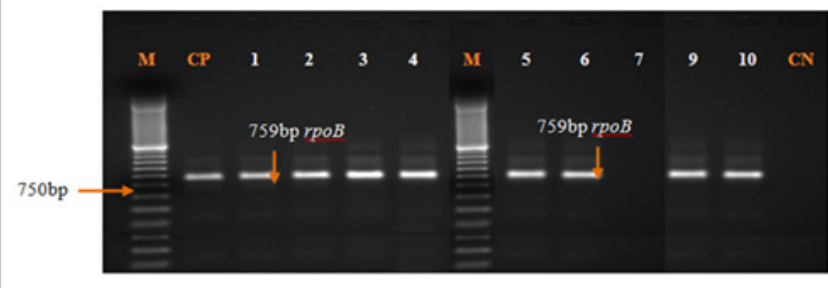

Figure I rpoB profiles of Pseudomonas aeruginosa isolates. Lanes I-4; 5-6; 9-10: Presence of Pseudomonas aeruginosa inanalyzed products; Lane 7:Absence of Pseudomonas in analyzed products; CP: Positive control (Pseudomonas aeruginosa ATCC 27853); CN: Negative control; M: Marker Gene Ruler I00bp (Bench Top, I00bp DNA Ladder, Promega Corporation, USA).

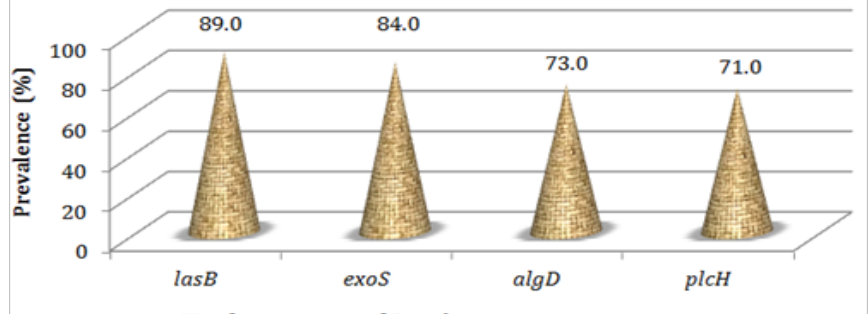

Virulence genes of Pseudomonas aeruginosa

Figure 2 Prevalence of virulence genes among all studied P. aeruginosa isolates. Las $\mathrm{B}$, elastase LasB-encoding gene; exoS, exoenzyme $\mathrm{S}$-encoding gene; algD, GDP-mannose 6 dehydrogenase AlgD (alginate)-encoding gene; plcH, haemolytic phospholipase $\mathrm{C}$ precursor-encoding gene.

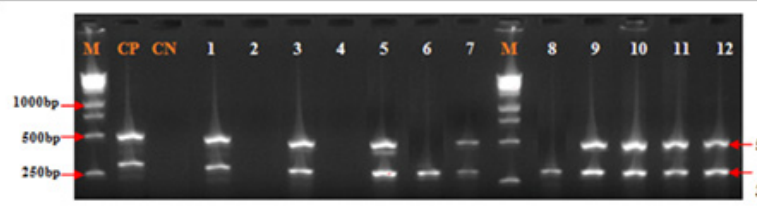
$300 \mathrm{bplasB}$

Figure 3 Electrophoretic profile of amplification products of virulence genes exoS and lasB in analyzed products. Virulence genes were present in analyzed products, Lane 1,3,5,7,9,10,II and 12: exoS and lasB; Lane 6 and 8: lasB; Virulence genes were absent in analyzed products, Lane 2 and 4. M: Marker Gene Ruler 250bp (Bench Top, I kb DNA Ladder, Promega Corporation, USA); lasB, elastase LasB-encoding gene; exoS, exoenzyme S-encoding gene.

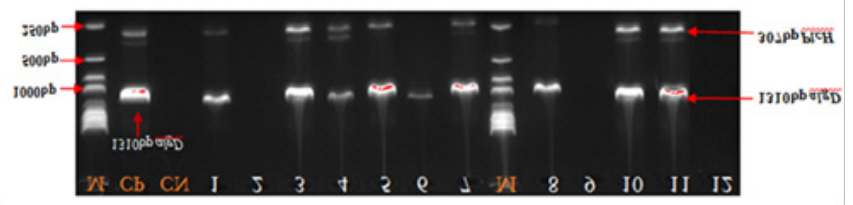

Figure 4 Electrophoretic profile of amplification products of virulence genes algD and PlcH in analyzed products. Virulence genes were present in analyzed products, Lane I,4,5,7,8, I0 and I I: algD and PIcH; Lane 3 and 6: algD;Virulence genes were absent in analyzed products, Lane 2, 9 and 12. M: Marker Gene Ruler 250bp (Bench Top, Ikb DNA Ladder, Promega Corporation, USA); algD, GDP-mannose 6-dehydrogenase AlgD (alginate)-encoding gene; plcH, haemolytic phospholipase $C$ precursor-encoding gene.

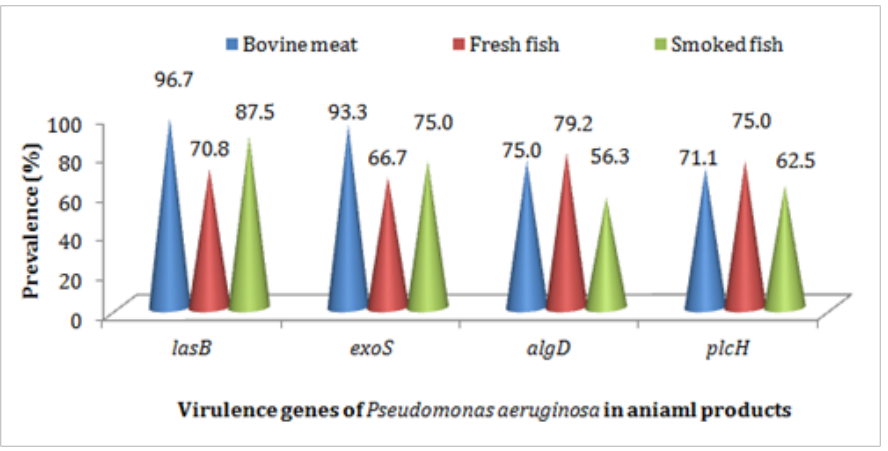

Figure 5 Prevalence of Pseudomonas aeruginosa virulence genes in animal products.

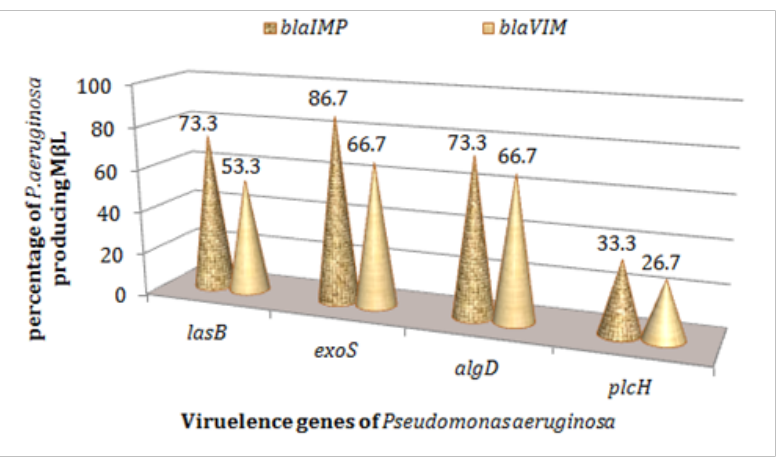

Figure 6 Percentage of metallo- $\beta$ lactamase according to virulence genes of Pseudomonas aeruginosa. M $\beta \mathrm{L}$ Imipenemase (IMP), Verona imipenemase (VIM).

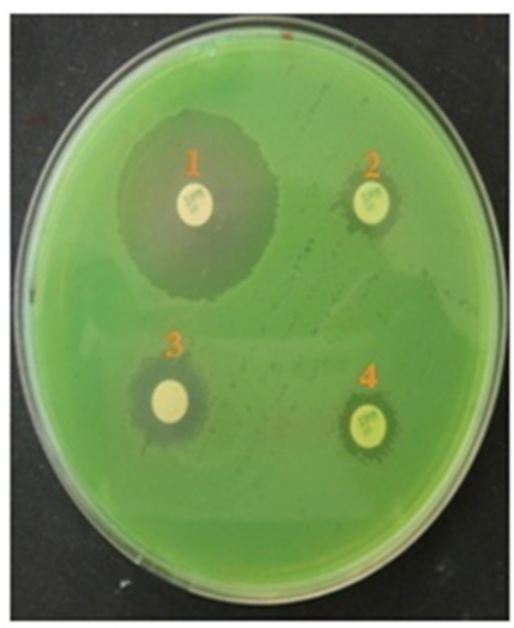

Figure 7 Metallo- $\beta$ lactamase (MBLs) producing by Pseudomonas aeruginosa isolated from animal products.

The test showed difference of $\geq 7 \mathrm{~mm}$ between the inhibition zone diameter

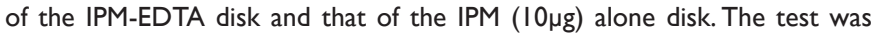
considered to be positive for producing of MBLs. Imipenem (IPM); I: IMP disks $(\mathrm{I} 0 \mu \mathrm{g})+4 \mu \mathrm{IEDTA}(0.5 \mathrm{M}, \mathrm{pH} 8)$; 2: IMP disks ( $\mathrm{I} 0 \mu \mathrm{g})$ without EDTA (0.5M, pH 8);

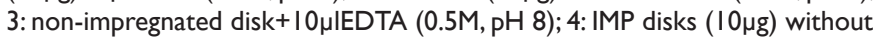
EDTA (0.5M, pH 8). 


\section{Discussion}

Morphological and biochemical characteristics confirmed that Pseudomonas aeruginosa is a motile (unipolar), gram negative, facultative, catalase positive, oxidative positive, nitrate reduction positive, non-fermentative and rod-shaped bacterium measuring 0.5 to $0.8 \mu \mathrm{m}$ by 1.5 to $3.0 \mu \mathrm{m}$ in size. Its optimum temperature for growth is $3^{\circ} \mathrm{C}$, but retains a growth potential at temperatures as high as $42^{\circ} \mathrm{C}$. P. aeruginosa strains produce two types of soluble pigments, a fluorescent pigment pyoverdin, and a blue pigment, pyocyanin. These results are consistent with those found by Virupakshaiah \& Hemalata who identified Pseudomonas aeruginosa from food isolates.

Identification of $P$. aeruginosa has traditionally relied on phenotypic methods. This still is the most accurate standard when dealing with typical isolates of $P$. aeruginos $a$. Moreover, biochemical testing takes long time to perform and requires extensive hands-on work by the technologist. Molecular methods have been reported to be superior to the phenotypic methods for identification of $P$. aeruginosa. ${ }^{5,16}$ Molecular identification by using rpoB gene showed $100(99.0 \%)$ of the strains were Pseudomonas aeruginosa. This result also indicated the strong discriminating power of the identification method using rpoB gene and confirmed the heterogeneity of the Pseudomonas aeruginosa observed by some authors. ${ }^{5,16}$ This high molecular identification rate showed that genomic studies are needed to confirm the exact taxonomic position of Pseudomonas aeruginosa.

The results showed also that all the virulence genes studied in this study were detected in the 100 strains of Pseudomonas aeruginosa. Therefore, strains isolated from bovine meat, fresh fish and smoked fish could host these virulence genes studied. Analysis revealed lasB gene $(89.0 \%)$ and exoS $(84.0 \%)$ were the most detected in this study and this could be justified by the fact that $P$. aeruginosa secretes elastase (LasB); a metalloproteinase involved in the host colonization and tissue damage. ${ }^{5}$ Previous studies have shown a high prevalence of the lasB gene in P. aeruginosa, irrespective of their isolation origin. ${ }^{5,6,24}$ The prevalence of ExoS observed in this study shows that the strain of Pseudomonas aeruginosa of animal origin could be involved in tissue destruction; ExoS gene is involved in lung infection and may be important for bacterial dissemination. . $^{6,24}$

The high prevalence of algD (73.0\%) gene observed in this study could be at the origin of the conversion of Pseudomonas aeruginosa strains to a mucoid phenotype overproducing alginates. ${ }^{6,25}$ This alginate prevalence indicates that isolated strains of animal products are involved in the formation of biofilms as alginates have been widely regarded as the major exopolysaccharides of the biofilm matrix. ${ }^{24,25}$ The prevalences of $\mathrm{plcH}(71.0 \%)$ gene showed that strains isolated were able of secreting hemolytic exoenzyme and phospholipase $\mathrm{C}$ and thus strains could be involved in pulmonary infections. ${ }^{26,27}$ Our results obtained in this study correlate with those proved by Bradbury et al., ${ }^{28}$ who proved that $P$. aeruginosa isolated from nosocomial infections were found to have an increased prevalence of virulence genes.

This study also showed that $P$. aeruginosa producing elastase (lasB) and harboring the alginate (algD) showed the same percentage of blaIMP genes $(73.3 \%)$. Those strains whish secreted exoenzyme (exoS) and harboring the alginate (algD) showed the same percentage of blaVIM genes $66.7 \%$. The strains of Pseudomonas aeruginosa harboring the $\mathrm{PlcH}$ gene indicated a production of metallo- $\beta$ lactamase (VIM and IMP) of less than 50\%. The prevalence of VIM and IMP was relatively high in the various animal products and therefore animal strains could be involved in serious infections. ${ }^{9,13,29}$ These same strains could also be involved in zonoses. The detection of virulence factors and metallo- $\beta$ lactamase in $P$. aeruginosa can prevent gene mutations and reduce the risk of multi resistance linked to this bacterium.

\section{Conclusion}

The simultaneous using of biochemical methods and rpoB genes provides more confident detection of $P$. aeruginosa by PCR. Determination of different virulence and resistance genes of $P$. aeruginosa isolates suggests that they are associated with different levels of intrinsic virulence and pathogenicity. Study indicated that MBL-producing isolates were associated with virulence factors and responsible for serious infections. Thus, good practices in hygiene procedures and food preparation are necessary to control and reduce biological risks.

\section{Acknowledgements}

None.

\section{Conflict of interest}

The author declares no conflict of interest.

\section{References}

1. Hemalata, VB, Virupakshaiah DBM. Isolation and Identification of food borne pathogens from Spoiled food samples. Int J Curr Microbiol App Sci. 2016;5(6):1017-1025.

2. Virupakshaiah DBM, Hemalata VB. Molecular identification of Pseudomonas aeruginosa from food borne isolates. Int J Curr Microbiol App Sci. 2016;5(6):1026-1032.

3. Franzetti L, Scarpellini M. Characterization of Pseudomonas spp. isolated from foods. Annals of Microbiology. 2007;57(1):39-47.

4. Abd El-Aziz DM. Detection of Pseudomonas spp. in Chicken and Fish Sold in Markets of Assiut City, Egypt. Journal of Food Quality and Hazards Control. 2015;2(3):86-89.

5. Khattab MA, Nour MS, ElSheshtawy NM. Genetic identification of Pseudomonas aeruginosa virulence genes among different isolates. $J$ Microb Biochem Technol. 2015;7(5):274-277.

6. Fadhil L, Al-Marzoqi AH, Zahraa MA, et al. Molecular and phenotypic study of virulence genes in a pathogenic strain of Pseudomonas aeruginosa isolated from various clinical origins by PCR: profiles of genes and toxins. Research journal of pharmaceutical, biological and chemical sciences. 2016;7(1):590-598.

7. Mitov I, Strateva T, Markova B. Prevalence of virulence genes among bulgarian nosocomial and cystic fibrosis isolates of Pseudomonas aeruginosa. Braz J Microbiol. 2010;41(3):588-595.

8. Ghanbarzadeh ZC, Khorshidi A, Firoozeh F, et al. Biofilm formation and virulence factors among Pseudomonas aeruginosa isolated from burn patients. Jundishapur J Microbiol. 2015;8(10):e22345.

9. Fallah F, Borhan RS, Hashemi A. Brief Communication Detection of bla(IMP) and bla(VIM) metallo- $\beta$-lactamases genes among Pseudomonas aeruginosa strains. Int J Burn Trauma. 2013;3(2):122-124.

10. Khorvash F, Reza M, Shabani S, et al. Detection of Pseudomonas aeruginosa producing Metallo- $\beta$-Lactamases (VIM, SME, AIM). In the clinical Isolate of Intensive Care Unite of AL-Zahra Hospital in Esfahan, Iran. J Med Bacteriol. 2015;4(3-4):15-23. 
11. Yousefi S, Farajnia S, Nahaei MR, et al. Detection of metallo-betalactamase-encoding genes among clinical isolates of Pseudomonas aeruginosa in northwest of Iran. Diagn Microbiol Infect Dis. 2010;68(3):322-325.

12. Tawfik AF, Shibl AM, Aljohi MA, et al. Distribution of Ambler class A, B and D beta-lactamases among Pseudomonas aeruginosa isolates. Sciverse Science Direct Burns. 2012;38(6):855-860.

13. Sheikh A, Rostami S, Jolodar A, et al. Detection of Metallo- $\beta$-Lactamases Among Carbapenem-Resistant Pseudomonas aeruginosa. Jundishapur J Microbiol. 2014;7(11):e12289.

14. Vahdani M, Azimi L, Asghari B. Phenotypic screening of extendedspectrum s-lactamase and metallobeta-lactamase in multidrugresistant Pseudomonas aeruginosa from infected burns. Ann Burns Fire Disasters. 2012;25(2):78-81.

15. AL-Kadhmi NA, AL-Thwaini AN, AL-Turk WA, et al. Studies on the Multidrug Resistance to Pseudomonas aeruginosa Isolated from Infected Wounds. Int J Curr Microbiol App Sci. 2016;5(5):963-970.

16. Gholami A, Majidpour A, Talebi-taher M, et al. PCR-based assay for the rapid and precise distinction of Pseudomonas aeruginosa from other Pseudomonas species recovered from burns patients. J prev med hyg. 2016;57(2):81-85.

17. NCCLS. Performance standards for antimicrobial susceptibility testing: fourteenth informational supplement M100-S14. USA: National Committee for Clinical Laboratory Standards; 2004.

18. Lee VT, Smith RS, Tummler BLS. Activities of Pseudomonas aeruginosa effectors secreted by the type III secretion system in vitro and during infection. Infect Immun. 2005;73(3):1695-1705.

19. Zimmermann A, Lüth J, Pauli U. Quantitative and qualitative evaluation of nine different extraction methods for nucleic acids on soya bean food samples. Zeistchrift für Lebensmittel-Untersuchung und-Forschung A. 1998;207(2):81-90.

20. Jonghe VD, Coorevits A, Hoorde KV, et al. Influence of Storage Conditions on the Growth of Pseudomonas Speciesin Refrigerated Raw Milk. Applied and environmental microbiology. 2011;77(2):460-470.
21. Benie CKD, Dadié A, N'Golo DC, et al. Comparative Evaluation of Molecular Detection Performance of Pseudomonas aeruginosa based on Phylogenetic Markers 16S RNAr, recA, rpoB and ITS1. Clin Microbiol. 2016;5(6):1-7.

22. Benie CKD, Dadié A, Guessennd N, et al. Characterization of virulence potential of Pseudomonas aeruginosa isolated from bovine meat, fresh fish, and smoked fish. European Journal of Microbiology and Immunology. 2017;7(1):1-10.

23. Strateva T. Microbiological and molecular-genetic investigations on resistance mechanisms and virulence factors in clinical strains of Pseudomonas aeruginosa. Sofia, Bulgaria; 2008. 210 p.

24. Streeter K, Katouli M. Pseudomonas aeruginosa: A review of their pathogenesis and prevalence in clinical settings and the environment. Infection Epidemiology and Medicine. 2016;2(1):25-32.

25. Whitney JC, Whitfield GB, Marmont LS, et al. Dimeric c-di-GMP isrequired for posttranslational regulation of alginate production in Pseudomonas aeruginosa. J Biol Chem. 2015;290(20):12451-12462.

26. Barker AP, Vasil AI, Filloux A, et al. A novel extracellular phospholipase $\mathrm{C}$ of Pseudomonas aeruginosa is required for phospholipid chemotaxis. Mol Microbiol. 2004;53(4):1089-1098.

27. Jackson AA, Gross MJ, Daniels EF, et al. Anr and its activation by $\mathrm{PlcH}$ activity in Pseudomonas aeruginosa host colonization and virulence. $J$ Bacteriol. 2013;195(13):3093-3104.

28. Bradbury RS, Roddam LF, Merritt A, et al. Virulence gene distribution in clinical, nosocomial and environmental isolates of Pseudomonas aeruginosa. J Med Microbiol. 2010;59(8):881-890.

29. Meena S, Garg SP, Sharma BP, et al. Study of Prevalence and Antimicrobial Susceptibility Pattern of Matello-Beta-Lactamase Producing Pseudomonas aeruginosa Isolated at a Tertiary Care Institute in North West Region of Rajasthan. India Int J Curr Microbiol App Sci. 2015;4(8):614-620. 